Volume 13

Issue 1 Revisiting the Life and Work of Raphaël

Lemkin

Article 5

4-2019

\title{
Three Theoretical Approaches to Lemkin's Definition of Genocide
}

Jonathan Hobson

University of Gloucestershire

Follow this and additional works at: https://digitalcommons.usf.edu/gsp

\section{Recommended Citation}

Hobson, Jonathan (2019) "Three Theoretical Approaches to Lemkin's Definition of Genocide," Genocide Studies and Prevention: An International Journal: Vol. 13: Iss. 1: 11-18.

DOI:

https://doi.org/10.5038/1911-9933.13.1.1592

Available at: https://digitalcommons.usf.edu/gsp/vol13/iss1/5

This Articles is brought to you for free and open access by the Open Access Journals at Digital Commons @ University of South Florida. It has been accepted for inclusion in Genocide Studies and Prevention: An International Journal by an authorized editor of Digital Commons @ University of South Florida. For more information, please contact digitalcommons@usf.edu. 


\title{
Three Theoretical Approaches to Lemkin's Definition of Genocide
}

\author{
Jonathan Hobson \\ University of Gloucestershire \\ Cheltenham, England
}

\section{Introduction}

Lemkin devised the term genocide as a response to the organized, mechanized, and institutionalized killings that were part of the Nazi Regime during the Second World War. In his 1944 work defining genocide and its processes, Lemkin identified genocide occurring across a range of different spheres of human and social life, including the political, social, cultural, economic, biological, physical, religious and moral. ${ }^{1}$ There are many good works that offer interpretations of genocide in the social and political forms and in its legal definitions. For example, Irvin-Erickson ${ }^{2}$ gives a significant account of Lemkin's life and work, including the genus of genocide as a concept, its application as a set of principles in human behavior, and Lemkin's efforts to see the act outlawed. Goldsmith's $\mathrm{s}^{3}$ review of the United Nations Genocide Convention, the first real legislation to directly address genocide, offers a valuable analysis on the difficulties such definitions of Genocide have created for achieving successful convictions. Others, such as Abdul Tejan-Cole, ${ }^{4}$ Barria and Roper, ${ }^{5}$ Hyearn and Simmonds, ${ }^{6}$ and Keppler ${ }^{7}$ discuss the efficacy of the international bodies subsequently established to prosecute genocide, arguing on their impact and on wider socio-political issues that have arisen in the context of pursuing prosecutions.

This article seeks to add to this body of work by examining three constituent parts of Lemkin's concept of genocide: the intent of the act, the aim of the act, and the techniques used to deliver the act. It does this by utilizing three different theoretical tools not previously applied together in this way. First, it employs Totten and Bartrop's ${ }^{8}$ genocide typologies to examine the dolus specialis (particular intent) of genocide to enact the "destruction of a nation or ethnic group." ${ }^{9}$ Second, it uses Galtung's ${ }^{10}$ concepts of direct, cultural, and structural violence to conceptualize the destruction of a group in its "essential foundations of life."11 Third, it applies Stanton's $\mathrm{s}^{12}$ ten-step chronology of genocide to detail how "techniques of genocide"13 are built upon in order to mobilize a group or nation to commit, or at least to allow, such an act to take place. Through these three interpretations the article aims to offer further understanding on what it is that makes genocide a unique crime in human nature, and, as Lemkin puts it, "a coordinated plan of different actions aiming at the

${ }^{1}$ Raphaël Lemkin, Axis Rule in Occupied Europe: Laws of Occupation, Analysis of Government, Proposal for Redress (Washington, DC: Carnegie Endowment for International Peace, 1944), 82-89.

${ }^{2}$ Douglas Irvin-Erickson, Raphaël Lemkin and the Concept of Genocide (Philadelphia: University of Pennsylvania Press, 2017).

${ }^{3}$ Katherine Goldsmith, "The Issue of Intent in the Genocide Convention and Its Effect on the Prevention and Punishment of the Crime of Genocide: Toward a Knowledge-Based Approach," Genocide Studies and Prevention: An International Journal 5, no. 3 (2010), 238-257.

${ }^{4}$ Abdul Tejan-Cole, "Is the ICC's exclusively African case docket a legitimate and appropriate intervention or an unfair targeting of Africans?" in Contemporary Issues Facing the International Criminal Court, ed. Richard H. Steinberg (Leiden: Brill, 2016), 366-379.

${ }^{5}$ Lilian Barria and Steven Roper, "How Effective are International Criminal Tribunals? An Analysis of the ICTY and the CTR," International Journal of Human Rights 9, no. 3 (2005), 349-368.

${ }^{6}$ Jo Hyeran and Beth Simmons, “Can the International Criminal Court Deter Atrocity?" International Organization 70, no. 3 (2016), 443-475.

${ }^{7}$ Elise Keppler, “Managing Setbacks for the International Criminal Court in Africa," Journal of African Law 56, no. 1 (2012), $1-14$.

${ }^{8}$ Samuel Totten and Paul Bartrop, The Genocide Studies Reader (London: Routledge, 2009), 40.

${ }^{9}$ Lemkin, Axis, 79.

${ }^{10}$ Johan Galtung and Dietrich Fischer, Johan Galtung: Pioneer of Peace Research (Berlin: Springer-Verlag 2013).

${ }^{11}$ Lemkin, Axis, 44.

${ }^{12}$ Gregory H. Stanton, “The Ten stages of Genocide," Genocide Watch, accessed October 6, 2018, http://www. genocidewatch.org/genocide/tenstagesofgenocide.html.

${ }^{13}$ Lemkin, Axis, 90.

Jonathan Hobson. “Three Theoretical Approaches to Lemkin's Definition of Genocide" Genocide Studies and Prevention 13, 1 (2019): 11-18. 02019 Genocide Studies and Prevention.

https://doi.org/10.5038/1911-9933.13.1.1592 
destruction of essential foundations of the life of national groups, with the aim of annihilating the groups themselves." ${ }^{14}$

The Dolus Specialis (particular intent) of Genocide: Totten and Bartrop's Genocide Typology There is debate over the use of dolus specialis (particular intent) in the modern legislation on genocide. Goldsmith, for instance, contends that such a requirement is unsuitable because "regardless of an individual's expressed intentions, he/she is still actively involved in genocide and plays a crucial part." ${ }^{15}$ Similarly, Irvin-Erickson argues that Lemkin's original conception of genocide regarded the motives behind the act as irrelevant to an international law as "every individual who participated in a program to destroy a nation would have different reasons for doing so."16 Both Goldsmith and Irvin-Erickson contend that placing an emphasis on the dolus specialis (particular intent) behind Genocide is unhelpful to definitions of genocide as the reasons why people participate in such an act vary greatly. For example, it may be driven not by an ideological hatred for another group but for the "benefits gained through genocide"17 such as resource or economic gain.

In contrast to Goldsmith and Irvin-Erickson the international professor of law William Schabas advocates for the inclusion of intent, which he argues is a vital portion of the international legislation that elevates "the stigmatization of genocide as the 'crime of crimes' for which the highest level of evil and malicious intent is presumed." ${ }^{18}$ Kai Ambos in his paper on the legal meaning and application of intent in international genocide prosecutions presents these debates as a conflict between a particular intent, dolus specialis, versus a wider concept of conditional intention, dolus eventualis, that does not require the same burden of proof but regards genocide as a group act in which different perpetrators might be aware of the event as a whole but would necessarily share the particular intent of group destruction. ${ }^{19}$ Nevertheless, the legislation as instituted by the international community holds specific intent to be a key dimension in constituting genocide as an intentional act to destroy a group.

Understanding the intent of genocide as a wholly destructive act is important not just sociologically and historically, but for the legal consequences of prosecution. Totten and Bartrop ${ }^{20}$ argue that, "rather than being simply an expression of passion, genocide is a rational instrument to achieve an end." They classify five types of genocide, discussing the rationale that might drive the particular intent to destroy in different circumstances. The first of Totten and Bartrop' $\mathrm{s}^{21}$ types is "retributive genocide," where revenge and punishment are used as the key justification for an attack. Common to much genocide throughout history, Totten and Bartrop argue that retribution is a "way of blaming the victim" that "flows from the dehumanization that has been fastened to the victims before they are attacked." As an example of this, we could consider elements of the genocide in the Rwandan conflict as retributive Genocide. The post-colonial collapse of unequal power structures meant the once politically and socially dominant Tutsi minority were targeted by members of the Hutu group partly in retaliation for the inequality they felt they had suffered during colonial rule.

The second of Totten and Bartrop's classifications is "institutional genocide," where genocide is used as a tool of the state or attacking organization to "manage" a target population. Totten and Bartrop argue that this form of genocide was a "universal aspect of conquest" in the ancient and medieval worlds, so much so that it was "embedded in the very notion of warfare." ${ }^{22}$ Often used in lieu of political solutions that were more resource-heavy and less likely to provide long-term

\footnotetext{
${ }^{14}$ Ibid., 79.

${ }^{15}$ Goldsmith, Intent, 252.

${ }^{16}$ Irvin-Erickson, Lemkin, 241.

${ }^{17}$ Ibid., 243.

${ }^{18}$ William Schabas, Genocide in International Law: The Crimes of Crimes (New York: Cambridge University Press, 2010$), 227$.

${ }^{19}$ Kai Ambos, "What does 'Intent to Destroy' in Genocide Mean?" International Review of the Red Cross, 91, no. 876 (2009), 84.

${ }^{20}$ Totten and Bartrop, Genocide, 40.

${ }^{21}$ Ibid., 41.

${ }^{22}$ Ibid.
} 
solutions, this driver for genocide is reflected in some of the bloody conquests during the crusades.

The third type, "utilitarian genocide," Totten and Bartrop argue is evident in the processes of colonialism and imperialism. Describing it as "a combination of ethnocentrism and simple greed." ${ }^{23}$ Utilitarian genocide often involves restriction, subjugation or killing of indigenous groups to simplify the acquisition of land and resources. One such example comes from British involvement in the invasion and subjugation of North America. Jones describes how systematic violence and the often deliberately induced spread of disease during the colonization of North America reduced indigenous populations from an estimated 7-10 million (possibly up to 18 million according to some estimates) to around 275,000. He recounts incidents of this as a deliberate (what we would now term as genocidal) process, for example in 1763 when British commander Lord Jeffery Amherst ordered that "You will Do well to try to Inoculate the Indians [with smallpox] by means of Blankets, as well as to try Every other method that can serve to extirpate this Execrable Race." 24

Where many earlier genocides were external to the perpetrating country and focused on acquisition of land and/or resources, Totten and Bartrop argue that modern genocides are more likely to occur as part of internal, domestic issues. They describe this as monopolistic genocide, their fourth category. "Monopolistic genocide" is about social ordering and it often reflected in internal power struggles and the and the enforcement of a perceived national identity. Examples of this form of genocide are common in the twentieth century. For instance, the Khmer Rouge in Cambodia undertook massacres within the country as part of the socio-political reordering of the state; and in the Balkans, the aftermath of the break-up of the Soviet bloc brought in its wake the violent persecution of different populations most notably in the former Yugoslavia.

The final of genocide Totten and Bartrop's typologies is genocide driven by ideological justification. This motive, they argue, is much more likely to incorporate extreme methods of extermination during a genocide. For instance, whilst the invasion and occupation of South America was clearly part of an imperial project, the religious ideology used to justify the treatment of the indigenous population meant that they were routinely dehumanized, brutalized, and condemned to lives of labor, sexual servitude, or simply put to death. The American studies writer David Stannard ${ }^{25}$ describes the conquest of South America as "the worst series of human disease disasters, combined with the most extensive and most violent program of human eradication that this world has ever seen." Jones ${ }^{26}$ gives the example of Hispaniola, modern-day Haiti and the Dominican Republic, using a contemporary eyewitness account to describe how the Spanish "forced their way into native settlements... slaughtering everyone they found there, including small children, old men, [and] pregnant women." Over three decades of Spanish control Jones claims that the population of the continent was reduced from an estimated 8 million to around 20,000.

Totten and Bartrop's typologies of genocide illustrate how genocide is driven through different forces, be they institutional, utilitarian, monopolistic, ideological, or a combination therein. Regardless of the drivers and the justifications used for genocide, however, the end of the process is the same: the destruction of a target group. In this sense, whether a dolus specialis (particular intent) or a dolus eventualis (conditional intention) is present does not impact on the event, although it may impact on the legal outcomes given the language used in international legislation. Totten and Bartrop ultimately tie their typologies together:

Genocide is a sustained purposeful action by a perpetrator to physically destroy a collective directly or indirectly, through interdiction of the biological and social reproduction of group members, sustained regardless of the surrender or lack of threat offered by the victim. ${ }^{27}$

\footnotetext{
${ }^{23}$ Ibid., 42.

${ }^{24}$ Adam Jones, Genocide: A Comprehensive Introduction, 2nd ed. (London: Routledge, 2011), 114.

${ }^{25}$ David Stannard, American Holocaust: The Conquest of the New World (New York: Oxford University Press, 1992$), 54$.

${ }^{26}$ Jones, Genocide, 108-110.

${ }^{27}$ Totten and Bartrop, Genocide, 54.
} 
The next section illustrates how the destruction of a group in a genocide is part of a complex act that involves more than just mass persecution and/or killings, but entails an embedded social machinery and a cultural acceptance of violence.

\section{The Destruction of a Group in its Essential Foundations of Life: Galtung's Direct, Cultural and Structural Violence}

The second element of genocide this paper considers is the concept of destruction of a group in its entirety, what Lemkin describes as the removal of "the essential foundations of the life of national groups, with the aim of annihilating the groups themselves." ${ }^{28}$ For Irvin-Erickson, "genocide in Lemkin's thought, was a social and political process of attempting to destroy human groups, not an act of mass killing." ${ }^{29}$ In this way, we can understand genocide as more than mass murder or extensive and extreme violence, as terrible as those events may be. Rather, genocide is the attempt to annihilate a cultural, ethnic ("racial"), or national group in its entirety, so that group, its history, and its social constructs no longer exist. Lemkin, ${ }^{30}$ with reference to the Nazi occupations in World War Two, describes this a "composite of different acts of persecution or destruction" ${ }^{31}$ that spans the political, social, cultural, economic, biological, physical, religious, and moral spheres.

Although not specifically a descriptor of genocide, the work of Johan Galtung offers a way to articulate the encompassing destructive processes genocide entails, and in doing so help to better understand what it is that makes something a genocidal event. Galtung developed a "phenomenology of violence, useful as a paradigm generating a wide variety of hypotheses." 32 Within this phenomenology of violence Galtung uses concepts of "direct, structural and cultural violence" to explain how different societal processes might exclude and victimize certain groups in society. ${ }^{33}$ For instance, we might consider gender inequality to variously involve direct violence against women, a structural restriction in opportunity and life chances, and a cultural approach to patriarchy that ingrains this behavior as "normal" in that societal context. In other words, it describes a process that spans all spheres of an individual's existence within a society. Applying Galtung's concepts of violence can also help to articulate genocide as the deliberate institutionalization of violence against a specific group, with the end-goal of their disintegration. In doing so, it helps to take Galtung's concepts of direct, structural, and cultural violence in reverse order.

Firstly, genocide is an act of cultural violence in the sense that it is a crime committed by one group identifying as against another. Although individuals may commit the individual acts of violence, genocide as a crime involves significant organization and, frequently, the convincing of a population, force, or army that this form of violence is the solution. In this sense, genocide needs to exist as a cultural concept before it can exist as a physical act. Using Galtung' $\mathrm{s}^{34}$ words, we can see how it is "Cultural violence [that] makes direct and structural violence look and feel right." Genocide involves embedding ideas of superiority and legitimate violence into cultural discourse, and for Galtung it is "the study of cultural violence [that] highlights the ways in which the acts of direct and structural violence are legitimized, internalized, and thus rendered acceptable in society." 35

Secondly, genocide requires a form of structural violence against the target group. Once a population has accepted a degree of cultural violence, then it is easier for a state or body to enact structural violence against the target group. Galtung ${ }^{36}$ describes this type of violence as a system of "structurally built-in alienation and repression," and in the case of genocide this might involve

\footnotetext{
${ }^{28}$ Lemkin, Axis, 79.

${ }^{29}$ Irvin-Erickson, Lemkin, 7.

${ }^{30}$ Lemkin, Axis, 82-89.

${ }^{31}$ Ibid., 92.

${ }^{32}$ Johan Galtung, “Cultural Violence,” Journal of Peace Research 27, no. 3 (1990), 294.

${ }^{33}$ Johan Galtung and Dietrich Fischer “Johan Galtung, Springer Briefs on Pioneers” Science and Practice 5 (2013), 39.

${ }^{34}$ Ibid., 39.

${ }^{35}$ Ibid.

${ }^{36}$ Ibid., 38.
} 
the organization of punitive and discriminatory legislation. For instance, in Nazi Germany a long process of anti-Jewish laws, victimization, and public discrimination preceded the holocaust. As with Nazi Germany, Galtung ${ }^{37}$ describes how structural violence can become an essential part of some states, either as a tool to manage resources or as a broader structure of social power. Such violence is no accident; it is embedded "within complex structures and at the end of long, highly ramified causal chains and cycles." Galtung's characterization of structural violence fits further with Lemkin's concept of Genocide as an act targeting a group in their essential foundations of life, for such violent structures as Galtung describes "leaves marks not only on the human body but also on the mind and the spirit." ${ }^{38}$

Finally, Genocide involves direct violence against a target population. Galtung regards direct violence as the most conspicuous form of in his phenomenology "visible to the unguided eye and to barefoot empiricism, is the stratum of direct violence with the whole record of direct cruelty perpetrated by human beings against each other and against other forms of life and nature in general. ${ }^{\prime 39}$ In terms of genocide, direct violence takes many forms and the international legislation for the crimes lists several of these, including killing members of a group or creating other actions designed to inflict on the group "conditions of life calculated to bring about its physical destruction in whole or in part." ${ }^{40}$ Galtung's definition associated as it is with the other forms of structural and cultural violence can also give a broader interpretation to direct violence to include actions against individuals, homes and business premises, and cultural spaces to name but a few. This is because direct violence is the manifestation of the longer term and often hidden or less visible processes of cultural conditioning to exclusion and violence. Direct violence is the conspicuous pinnacle of a process in which a "steady flow through time of cultural violence" is overlain with the "rhythms of structural violence" so as to create a situation in which "patterns of exploitation are building up, wearing out, or torn down, with the protective accompaniment of penetration-segmentation preventing consciousness formation, and fragmentation- marginalization preventing organization against exploitation and repression." ${ }^{41}$ In such a connection, genocide is the culmination of a complex socio-political, often psychological, process of acclimatization to exclusion and violence.

Galtung's three concepts offer an important perspective on genocide. The dimensions of violence are interlinked processes, as Galtung describes: "Direct violence is an event; structural violence is a process with ups and downs; cultural violence is an invariant, 'permanence'." ${ }^{42}$ Taken together they illustrate the development of persecution that takes places as a society moves from exclusion, to incitement, and finally to direct and violent action. The following section uses Stanton's phased model to develop this concept of a chronology of genocide.

\section{The Techniques of Genocide: Stanton's Stages of Genocide}

For Lemkin, genocide is "a composite of different acts of persecution or destruction" that includes, as examples of acts that were committed by the Nazi forces against the Jewish and other populations of occupied Europe, "infringement upon honor and rights... transgression against life, property and religion, or science and art...[acts that] encroach unduly in the fields of taxation and personal services... those which cause humiliations, debilitation and understanding, and danger to health... measures for weakening or destroying political, social, and cultural elements in national groups." 43 These examples serve to illustrate the orchestrated and interrelated program of acts designed, as the previous two sections have shown, to intentionally destroy a group in essential foundations. The nature of the acts, however, vary depending on a great many factors, including the social and

\footnotetext{
${ }^{37}$ Galtung, Violence, 293.

${ }^{38}$ Ibid., 294.

${ }^{39}$ Ibid., 295.

${ }^{40}$ United Nations. Rome Statute of the International Criminal Court, July 17, 1998 and corrected by process-verbaux of November 10, 1998, July 12, 1999, November 30, 1999, May 8, 2000, January 17, 2001 and January 16, 2002 (UN Doc. A/ CONF.183/9).

${ }^{41}$ Galtung, Violence, 294.

${ }^{42}$ Ibid., 294.

${ }^{43}$ Lemkin, Axis, 92.
} 
cultural characteristics of the perpetrating and victim groups, the power relationships between the groups, and other underlying ideological positions that may be employed as part of the 'justification' for genocide.

Recognizing this "composite of different acts" and the sequences they could follow is an important dimension to understanding genocide; both in the build-up and possible intervention, and in analyzing events post factum. In trying to establish a chronology to genocide, Gregory Stanton has developed a phased approach with a "stages of genocide" model that considered genocide as a process or a series of techniques similar to Lemkin's description. ${ }^{44}$ Stanton established and is president of the organization "Genocide Watch," which aims to "predict, prevent, stop, and punish genocide." 45 The model devised by Stanton and Genocide Watch initially comprised of eight, then ten, then 12 stages of genocide, and aims to highlight the processes a society goes through as part of a genocidal event. Here, the ten-stage version model is used as an example.

Stanton's Ten Stages of Genocide can be categorized into four groups. The first group contains those stages that are concerned with the identification and othering of the target group to establish them as deviant, different, and dangerous. For Stanton, ${ }^{46}$ this is achieved through "Classification" and "Symbolization," which is the use of both physical symbols and cultural knowledge to create the concept of difference. This is important in identifying the target group, but also in creating for the perpetrators a collective identity that can later be manipulated into genocidal intent. In their work, Adorno and Horkheimer ${ }^{47}$ describe how such othering is a key ingredient in creating the groundwork for discrimination and violence. Focusing on the Nazi treatment of Jews in and around the Second World War, they described how "the fascists do not view the Jews as a minority but as an opposing race, the embodiment of the negative principle." ${ }^{48}$

The second broad category of Stanton's typology relates to a process of organized statesanctioned inequality and division: what he terms "Discrimination" and "Dehumanization." 49 This is the application of the principles of othering to social and cultural institutions and to the life of the target group. For Zygmunt Bauman ${ }^{50}$ this is a key aspect of the group-crime that is genocide, it is the physical expression of othering and racism, which is "a form of social engineering."

The third grouping of Stanton's stages incorporate "Organization," "Polarization," "Preparation," and "Persecution." Collectively, these relate to intensified discrimination, increased use of violence, and preparation for the removal and/or destruction of a target population. As a group act, genocide requires a high degree of organization and management, and these stages of Stanton's work emphasize the deliberate and orchestrated nature of the crime and the shift from violence to disintegration and extermination of the target group. For instance, Bauman ${ }^{51}$ cites Joseph Goebbels (Minister of Propaganda for Nazi Germany) speaking on the escalating levels of violence required to manage the Jewish population of Europe: "there is no hope of leading the Jews back into the fold of civilized humanity by exceptional punishments. They will forever remain Jews, just as we are forever members of the Aryan Race."

The final grouping comprises stages nine and ten of Stanton's process, and deals with "Genocide" and "Denial" in its aftermath. Here we can see some of the complexity of categorizing genocidal acts as the focus on the "destruction of the group themselves" 52 means that there is often the chance for perpetrators to deny such intent. This, along with the requirement to prove

\footnotetext{
${ }^{44}$ Ibid., 82.

${ }^{45}$ Genocide Watch, "The Mission of Genocide Watch," About Us, accessed October 5, 2018, http://www.genocidewatch. org/aboutus/missionstatement.html.

${ }^{46}$ Stanton, Stages.

${ }^{47}$ Theodor W. Adorno and Max Horkheimer, "Elements of Anti-Semitism," in Theories of Race and Racism: A Reader, eds. Les Back and John Solomos (London: Routledge, 2000), 271-276.

${ }^{48}$ Ibid., 271.

${ }^{49}$ Stanton, Stages.

${ }^{50}$ Zygmunt Bauman, "Modernity, Racism and Extermination," in Theories of Race and Racism: A Reader, eds. Les Back and John Solomos (London: Routledge, 2009), 283.

${ }^{51}$ Ibid., 285.

${ }^{52}$ Lemkin, Axis, 79.
} 
the intent and focus of the act, means that it is often particularly difficult to prosecute genocide, as subsequent legal cases have borne out.

\section{Conclusion}

Lemkin's original definition of genocide reflected a series of crimes so great that they necessitated a new concept. This article seeks to add to the discussion, dividing Lemkin's concept of genocide into three interconnected parts and examining each in turn. In the first instance, debates around the specific intent of genocide illustrate the restrictive nature of dolus specialis (particular intent) in international legislation. This is more than just semantics; it reaches to the heart of genocide as a crime and as a prosecutable offence. The emphasis placed on motive in international legislation has, on the one hand served to elevate genocide as the "crime of crimes," ${ }^{53}$ distinguished from other internationally legislated acts of extreme violence. It has also, however, made it difficult to successfully prosecute genocide as is illustrated in the relatively low levels of genocide prosecution achieved by the International Criminal court to date. ${ }^{54}$ It also, according to Irvin-Erickson, moves us away from the "broad conceptions of national and national belonging" 55 that Lemkin sought as a basis to a genocide law that was broad in its applicability. Totten and Bartrop's genocide typologies help with this discussion, illustrating how different combinations of institutional, utilitarian, monopolistic, and ideological drivers have been used to justify genocide and galvanize populations into action. The typologies help to set up genocide as a complex socio-political act, which is expanded upon using Galtung's concepts of direct, structural, and cultural violence.

Galtung's work has not, to my research, been used as an analytical tool in genocide studies to date. His phenomenology of violence structured around a triangle of direct, cultural and structural violence offers an important tool for illustrating how genocide is a deliberate, long term and multifaceted process of social manipulation and victimization across all realms of social life. Galtung's work also illustrates the role of power imbalance within genocide, both in the act of direct violence and in the more pervasive but less visible constructions of cultural and structural violence that often precede the widespread violence of a genocidal event. This complexity is illustrated in the final section, which groups Stanton's well-established phased stages of genocide to offer a useful guide to some of the pervasive processes that Galtung identifies. Stanton's work is a very practical and empirical account of genocide processes, applying Galtung's work to it here can help to illustrate how such techniques of genocide mobilize a group or nation to commit, or at least to allow, such an act to take place. Through these three different interpretations, this paper hopefully offers further understanding to what it is that makes genocide a unique crime in human nature.

\section{Bibliography}

Ambos, Kai. "What does 'Intent to Destroy' in Genocide Mean?" International Review of the Red Cross 91, no. 876 (2009), 833-858. https://doi.org/10.1017/S1816383110000056

Adorno, Theodor W. and Max Horkheimer. "Elements of Anti-Semitism." In Theories of Race and Racism, edited by Les Back and John Solomos, 271-276. London: Routledge, 2000.

Barria, Lilian and Steven Roper. "How Effective are International Criminal Tribunals? An Analysis of the ICTY and the CTR." International Journal of Human Rights 9, no 3 (2005), 349-368. https://doi.org/10.1080/13642980500170782

Bauman, Zygmunt. "Modernity, Racism and Extermination." In Theories of Race and Racism: A Reader, edited by Les Back and John Solomos, 277-293. London: Routledge, 2000.

Galtung, Johan and Dietrich Fischer. Johan Galtung: Pioneer of Peace Research. Berlin: SpringerVerlag, 2013. https://doi.org/10.1007/978-3-642-32481-9

Galtung, Johan. “Cultural Violence.” Journal of Peace Research 27, no. 3 (1990), 291-305. https://doi. org/10.1177/0022343390027003005

Genocide Watch. "The Mission of Genocide Watch." About Us. Accessed October 5, 2018.

\footnotetext{
${ }^{53}$ Schabas, Genocide, 227.

${ }^{54}$ Jonathan Hobson, "Prosecuting Lemkin's Concept of Genocide: Successes and Controversies," Genocide Studies and Prevention 13, no. 1 (2019), 19-32.

${ }^{55}$ Irvin-Erickson, Lemkin, 241.
} 
http://www.genocidewatch.org/aboutus/missionstatement.html.

Goldsmith, Katherine. "The Issue of Intent in the Genocide Convention and Its Effect on the Prevention and Punishment of the Crime of Genocide: Toward a Knowledge-Based Approach." Genocide Studies and Prevention: An International Journal 5, no. 3 (2010), 238-257. https://doi.org/10.3138/gsp.5.3.238

Hobson, Jonathan. "Prosecuting Lemkin's Concept of Genocide: Successes and Controversies." Genocide Studies and Prevention 13, no. 1 (2019), 19-32.

Hyeran, Jo and Beth Simmons. "Can the International Criminal Court Deter Atrocity?" International Organization 70, no. 3 (2016), 443-475. https://doi.org/10.1017/S0020818316000114

Irvin-Erickson, Douglas. Raphaël Lemkin and the Concept of Genocide. Philadelphia: University of Pennsylvania Press, 2017. https://doi.org/10.9783/9780812293418

Jones, Adam. Genocide: A Comprehensive Introduction, 2nd ed. London: Routledge, 2011.

Keppler, Elise. "Managing Setbacks for the International Criminal Court in Africa." Journal of African Law 56, no. 1 (2012), 1-14. https://doi.org/10.1017/S0021855311000209

Lemkin, Raphaël. Axis Rule in Occupied Europe: Laws of Occupation, Analysis of Government, Proposal for Redress. Washington, DC: Carnegie Endowment for International Peace, 1944.

Schabas, William. Genocide in International Law: The Crimes of Crimes. New York: Cambridge University Press, 2010.

Stannard, David. American Holocaust: The Conquest of the New World. New York: Oxford University Press, 1992.

Stanton, Gregory H. “The Ten Stages of Genocide." Accessed October 6, 2018. http://www. genocidewatch.org/genocide/tenstagesofgenocide.html.

Tejan-Cole, Abdul. "Is the ICC's Exclusively African Case Docket a Legitimate and Appropriate Intervention or an Unfair Targeting of Africans?" In Contemporary Issues Facing the International Criminal Court, edited by Richard H. Steinberg, 366-379. Leiden: Brill, 2016. https://doi.org/10.1163/9789004304451 043

Totten, Samuel and Paul Bartrop. The Genocide Studies Reader. London: Routledge, 2009.

United Nations. Rome Statute of the International Criminal Court. July 17, 1998 and corrected by process-verbaux of November 10, 1998, July 12, 1999, November 30, 1999, May 8, 2000, January 17, 2001 and January 16, 2002. UN Doc. A/CONF.183/9. 